\title{
Mass mortality event in a small saline lake (Lake Rogoznica) caused by unusual holomictic conditions*
}

\author{
ANTE BARIĆ, BRANKA GRBEC, GROZDAN KUŠPILIĆ, IVONA MARASOVIĆ, \\ ŽIVANA NINČEVIĆ and IVANA GRUBELIĆ \\ Institute of Oceanography and Fisheries, 21000 Split, P.O.BOX 500, Croatia. E-mail: baric@izor.hr
}

\begin{abstract}
SUMMARY: The study of a small saline eutrophic lake was performed under meromictic and holomictic conditions. The meromictic period was characterised by anoxic conditions in the bottom layer with high sulphide and nutrient concentrations. The depth of the nutricline varied as affected by thermohaline conditions in the water column. In late summer 1997, holomictic conditions replaced ordinary meromitic conditions in the lake. This transformation caused anoxia to spread throughout the water column and mass mortality of almost all the organisms occured. Thereafter, oxic conditions were reestablished slowly as the new phytoplankton population developed. As a consequence of the particulate organic matter decay, inorganic $\mathrm{N}$ and $\mathrm{P}$ concentrations increased and had doubled approximately six weeks after the mass mortality. The revitalisation of the phytoplankton population was initiated immediately after the mass mortality by the development of "microflagellate" species, which were favoured by the high ammonia concentrations. The larger phytoplankton species (diatoms and dinoflagellatae) developed at the expense of smaller ones when nitrate became the dominant nutrient in the water column. A year after the mass mortality the composition of the phytoplankton population was the same as before.
\end{abstract}

Key words: saline lake, mass mortality, nutrient regeneration, phytoplankton, benthic communities.

RESUMEN: EVENTO DE MORTALIDAD MASIVA EN UN PEQUEÑO LAGO SALINO (LAGO ROGOZNICA) CAUSADO POR INUSUALES CONDICIONES DE HOLOMIXIA. - Se realizó un estudio de un lago salino eutrófico bajo condiciones de meromixia y holomixia. El período meromíctico se caracteriza por condiciones de anoxia en la capa profunda con elevadas concentraciones de nutrientes y sulfhídrico. La profundidad de la nutriclina variaba en función de las condiciones termohalinas de la columna de agua. Al final del verano de 1997, las condiciones de holomixia reemplazaron las de meromixia del lago. Esta transformación causó anoxia que se extendió por toda la columna de agua, lo que se tradujo en una mortalidad masiva de todos los organismos. Después de este evento las condiciones aeróbicas se restablecieron lentamente mientras la nueva población de fitoplancton se desarrollaba. Como consecuencia de la disminución de la materia orgánica particulada, las concentraciones de N y P inorgánico se incrementaron y aumentaron el doble aproximadamente seis semanas después de la mortalidad masiva. La revitalización de la población de fitoplancton se produjo inmediatamente después de la mortalidad masiva por la aparición de especies de "microflagelados", que se veían favorecidos por la alta concentración de amonio. Las especies de fitoplancton de mayor tamaño (diatomeas y dinoflagelados) se desarrollaronn a expensas de las más pequeñas cuando el nitrato se convertía en el nutriente dominante en la columna de agua. Un año después de la mortalidad masiva la composición de la población de fitoplancton era la misma que había anteriormente.

Palabras clave: lago salino, mortalidad masiva, regeneración de nutrientes, fitoplancton, comunidades bentónicas.

\section{INTRODUCTION}

Specific physical and chemical limnology cycles of small saline lakes are well documented in many

\footnotetext{
*Received June 26, 2000. Accepted December 3, 2002.
}

parts of the world: for example, the mesothermic sulfatochloride Lake Mahega in Uganda (Melack and Kilhman, 1972), the hypersaline Solar Lake on the Sinai coast (Cohen, et al., 1977; Jørgensen et al., 1979), and a meromictic salt lake (Mahoney Lake) in British Columbia (Northcote and Hall, 
1983; Overmann et al., 1991), etc. Many lakes as well as fjords, which are chemically and thermally stratified, are characterised by anoxic, sulphidebearing bottom water (Millero, 1991) and associated nutriclines (Woo Han and Chul Park, 1999; Hecky, 2000).

A similar occurrence of sulphide and high concentrations of nutrients were for the first time recorded from the bottom layer of a salt lake (Lake Rogoznica) on the eastern Adriatic coast by Buljan (1956). All the other investigations of biological and chemical characteristics of the lake showed permanent stratification of the entire water column and the presence of sulphide in the bottom layer (Ciglenečki et al., 1996, 1998; Mihelčić et al., 1996; Stipaničev and Branica, 1996; Viličić et al., 1996). The community of the lake consisted of a limited number of species (adapted to the specific physical-chemical conditions in the lake). All the species showed very high density. Of benthic species, the mussel Mytilus galloprovincialis and tunicate Pyura dura were highly dominant. The heterotrophic ebridian microflagellate Hermesinum Adriaticum and the diatom Eunotia spp were dominant in the phytoplankton population, while the zooplankton community was characterised by oligotrich ciliates and a monoculture of the copepod Acartia Italica.

At the end of September 1997 holomictic conditions replaced ordinary meromitic conditions in the lake, the entire water column became anoxic and a sharp hydrogen sulphide odour was widespread. According to Stošić (1941), such a sudden occurrence of hydrogen sulphide in the entire water column of the lake has been noticed in the past, but it has never been explained. The sampling of the lake started two days after the occurrence of the hydrogen sulphide event. A mass mortality of almost all plankton and benthic organisms was observed. The entire phytoplankton community was destroyed, with the exception of rare phytoplankton organisms, mostly benthic Pennatae diatoms $\left(10^{3}\right.$ cells $\left./ \mathrm{dm}^{3}\right)$, which are easily adaptable to hypoxic conditions. Cyst stages of different phytoplankton species and a large number of empty theca of a typical red tide dinoflagellate species (Ceratium furca) were also found. Analyses of the benthic material showed mortality of almost all the macrobenthic species. Mainly dead individuals were found in the settlement of tunicate Pyura dura, whereas the survival percentage of Mytilus galloprovincials was slightly higher in the mediolittoral zone $(0-0.5 \mathrm{~m})$. It was also established that all the fouling species on mussel shells were also dead. Empty tubes of sedentary polychaetes, dead bryozoans, sponges and colonial tunicates were recorded. Powilleit and Kube (1999) and Bianchi et al. (2000) for the Baltic Sea described similar effects of oxygen depletion and anoxia on the benthic community.

The aim of this study is to present the revitalisation of the phytoplankton community in the lake after the mass mortality of the entire community, which was coupled with the changes in the physicochemical conditions in the water column.

\section{MATERIAL AND METHODS}

The lake $\left(43^{\circ} 31^{\prime} \mathrm{N}, 15^{\circ} 58^{\prime} \mathrm{E}\right)$ is very small and relatively shallow. It is about $5,000 \mathrm{~m}^{2}$ in area and has a maximum depth of $13 \mathrm{~m}$ (Fig. 1). The coast is
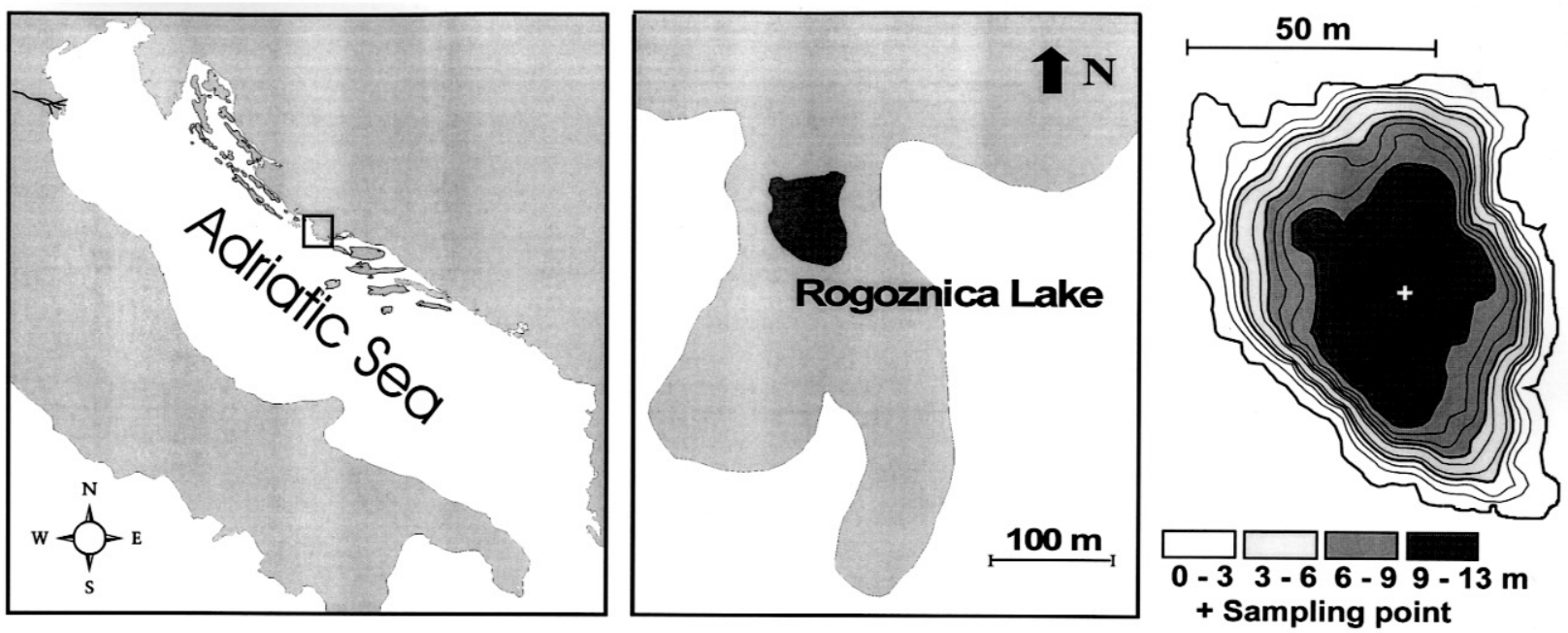

FIG.1. - Geographical position of the Rogoznica Lake. 
steep, a cliff, which provides good wind protection. The lake communicates with the adjacent sea through porous carbonate rocks (Magaš and Maričić, 1973) and responds to the tidal oscillations, which are around $0.5 \mathrm{~m}$ in the middle Adriatic (Buljan and Zore-Armanda, 1976). According to salinity values the lake water is of marine origin, while freshwater impact could only be found in the surface layer up to $2 \mathrm{~m}$ depth due to precipitation and freshwater run-off. At the beginning of our survey in 1994-1995 samples were taken at six stations. However, since horizontal homogeneity of investigated parameters was recorded, further samplings were performed at a station in approximately the centre of the lake at its deepest point (Fig. 1).

Water samples were collected with plastic Nansen samplers (Hydro-Bios, Kiel, Germany) in March, July and November 1994 and February 1995, and fortnightly between October and December 1997. In addition, samplings were performed in December 1995 (only phytoplankton) and September 1998 (all the parameters). During the 1994-1995 period the temperature was measured by reverse thermometers (Richter and Wiese, accuracy \pm $0.01^{\circ} \mathrm{C}$ ). Salinity was determined in the laboratory using an inductive salinometer (Beckman RS 10, accuracy $\pm 0.003 \%$ o). Vertical temperature and conductivity profiles measurements were initiated in 1997 and carried out by CTD probe (Idronaut, Type OS 316, Milan, Italy). Salinity and density of the water column were calculated using the modified UNESCO formula.

From the collected water samples sub-samples were separated for analysis of sulphide, oxygen, $\mathrm{pH}$ and nutrients as well as phytoplankton density and composition. The sulphide samples $(20 \mathrm{ml})$ were taken in glass flasks spiked with $2 \mathrm{ml}$ of the mixed diamine reagent (Cline, 1969) immediately after sampling and strongly shaken for the colour development. During the 1994-1995 sampling period the occurrence of sulphide was checked in a qualitative way only by the visible colour changes, while in the 1997 period the quantitative spectrophotometric analysis was performed. The samples were stored and transported in a portable refrigerator and after 79 hours they were analysed in the laboratory using a Gilford Stasar III Spectrophotometer after Cline (1969). The calibration was performed using standards prepared by the solution of $\mathrm{Na}_{2} \mathrm{~S} \times 9 \mathrm{H}_{2} \mathrm{O}$ in de-aerated Mili-Q water and analysed 7-9 hours after the preparation in the same way as the natural samples. Dissolved oxygen concentrations were determined by the standard Winkler method (Strickland and Parsons, 1968). The $\mathrm{pH}$ of the water samples was measured with a portable Metrohm $\mathrm{pH}$ meter. The nutrient samples were spiked with $\mathrm{HgCl}_{2}$ solution, stored and transported in a portable refrigerator until analysis in the laboratory that took place 7-9 hours after the sampling. Nutrient concentrations were determined by standard photometric methods described by Grasshoff (1976) using a Technicon Autoanalyzer II. Organic nitrogen and phosphorus were calculated from the difference between total and inorganic nitrogen and phosphorus respectively. Total nitrogen and total phosphorus were determined after the sample oxidation $(3.5 \mathrm{~h})$ in an UV-photo-oxidation unit (Ace Glass Inc., Vineland NJ, USA) after Armstrong et al. (1966).

Density and composition of the phytoplankton community were determined using an inverted microscope by the Utermöhl (1958) sedimentation method. Phytoplankton samples were preserved in $2 \%$ neutralised formaldehyde solution. Chlorophyll $a$ was determined on acetone extracts (Strickland and Parsons, 1968) using a Turner Model 112 fluorometer, after filtration through Whatman GF/F glass filters. Small phytoplankton cells were counted using the epifluorescence microscopy (Waterbury et al., 1979; Maugeri et al., 1990). Seawater samples $(15 \mathrm{ml})$ were filtered through a $2 \mu \mathrm{m}$ Nucleopore filter. The filter was laid on a slide using oil, covered with a cover slip and examined using an oil immersion lens. The samples were exposed to the blue light under which phycoerythrin in cyanobacteria appeared yellow and chlorophyll $a$ in eucariotic picoplankton red.

Benthic samples were collected by SCUBA divers along the 0 to $10 \mathrm{~m}$ depth transect from a surface area of $1 / 25 \mathrm{~m}^{2}$. Samples were preserved in $4 \%$ formaldehyde solution.

\section{RESULTS AND DISCUSSION}

\section{Characteristics of the lake in the meromictic period}

\section{Physical characteristics of the water column}

During the meromictic period, the water column was stratified and stable in all the seasons, particularly in March and July 1994 (Fig. 2). Stability was lowest during the coldest part of the year, in February 1995 . The depth of the surface layer was sea- 

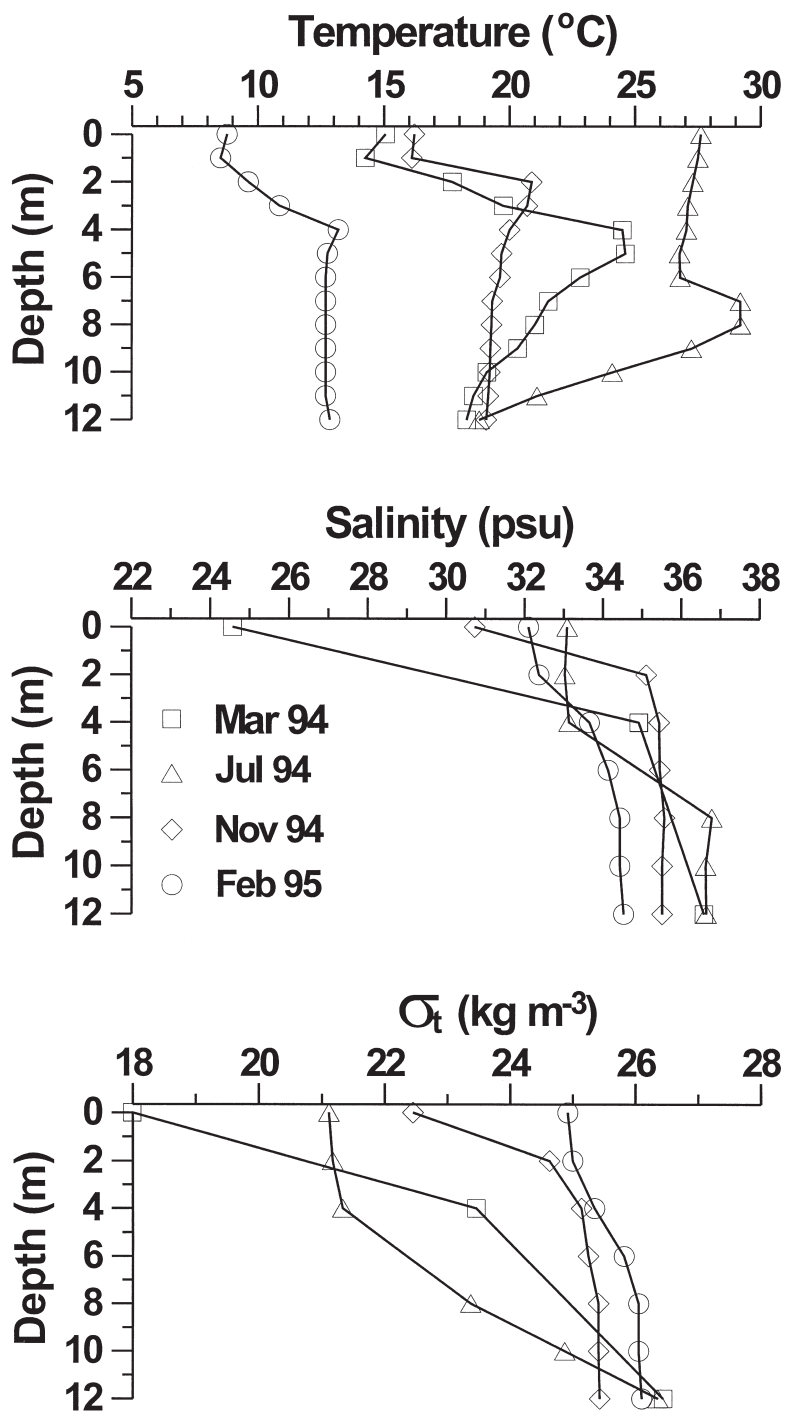

FIG.2. - Vertical distribution of temperature, salinity and density in the water column during the meromictic period 1994-1995.

sonally variable, as was the picnocline depth. Homogeneous horizontal temperature and salinity distribution at all the six stations indicated that thermohaline characteristics of the lake are mainly under the impact of vertical heat and salt exchange. Thermally inverted stratification in upper layers showed the presence of a warm interlayer for most of the year. This interlayer was formed at the end of the warm period of the year when vertical heating from the atmosphere has ceased. However, the precise mechanism and time of its appearance are difficult to define due to the lack of relevant hydro- and atmospheric data. The interlayer temperature changes followed those of the surface temperature, while the bottom temperature was practically constant almost all year round. The bottom layer water was dense $\left(\sigma_{\mathrm{t}} 25.5-26.6 \times 10^{-3} \mathrm{~kg} \mathrm{~m}^{-3}\right)$, with the high- est salinity (34.45-36.69\%o) and lowest temperature $\left(13-19^{\circ} \mathrm{C}\right)$.

\section{Chemical variables}

Oxygen saturation, $\mathrm{pH}$ values, nutrient concentrations and Secchi disk depths for two typical seasons (winter and summer) in the meromictic period are shown in Figure 3. Extremely high oxygen saturation values (up to $350 \%$ in the interlayer) during summer 1994 indicated a very high primary production in the lake. The absence of over-saturation in winter, even in the presence of high nutrient concentrations up to $2 \mathrm{~m}$ depth, suggests that temperature and water transparency are the main primary production control factors in the lake (Fig. 3).

The bottom layer was characterised by permanent anoxia, low $\mathrm{pH}$ values, and the presence of sulphide in all the seasons. The sulphide concentration was established to amount to $8.2 \times 10^{-5}-5.3 \times 10^{-4}$ mmol m${ }^{-3}$ by Ciglenički et al. (1996).

As the result of particulate organic matter decay and nutrient remineralisation, high nutrient concentrations were present in the bottom layer and a sharp nutricline occurred above the oxycline. The depth of the nutricline was seasonally variable and mainly dependent on the thermohaline conditions of the lake. Phytoplankton abundance was much higher in the layer above the nutricline than in the layer below it, as shown below.

\section{Phytoplankton community}

The phytoplankton community in the lake showed a low number of species, whilst during the bloom few species were dominant (Ceratium furca, Prorocentrum arcuatum, Thalassiosira sp., Fragilaria sp., Hermesinum adriaticum, Chaetoceros sp.) (Table 1), depending on the season. However, phytoplankton abundance was very high $\left(10^{4}-10^{6}\right.$ cells $\left.\mathrm{dm}^{-3}\right)$. In general, it is higher in the interlayer $\left(10^{5}\right.$ $10^{6}$ cells $\mathrm{dm}^{-3}$ ) than in the surface layer. In the layer below the thermocline, which in the most cases corresponded to the layer below the nutricline, the phytoplankton abundance was extremely low (Viličić $e t$ al., 1996). This may be related to the interlayer temperature, which in general is higher than the temperature of the surface and the bottom layers (Fig. 2). During the period of less developed stratification and relatively high water temperature, as in November 1994, when the temperature of the water column was practically homogenous (from $2 \mathrm{~m}$ to the bot- 
July 1994

$\mathrm{pH}$

$\begin{array}{llllllll}7.0 & 7.2 & 7.4 & 7.6 & 7.8 & 8.0 & 8.2 & 8.4\end{array}$

$\mathrm{O}_{2}(\%)$

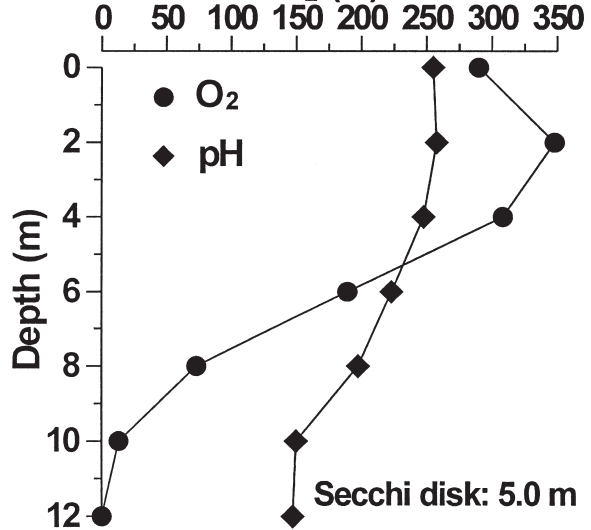

$\mathrm{NO} 3+\mathrm{NO} 2\left(\mathrm{mmol} \mathrm{m}^{-3}\right)$

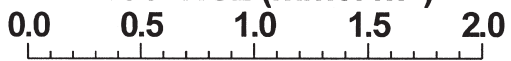

$\mathrm{NH} 4\left(\mathrm{mmol} \mathrm{m}^{-3}\right)$

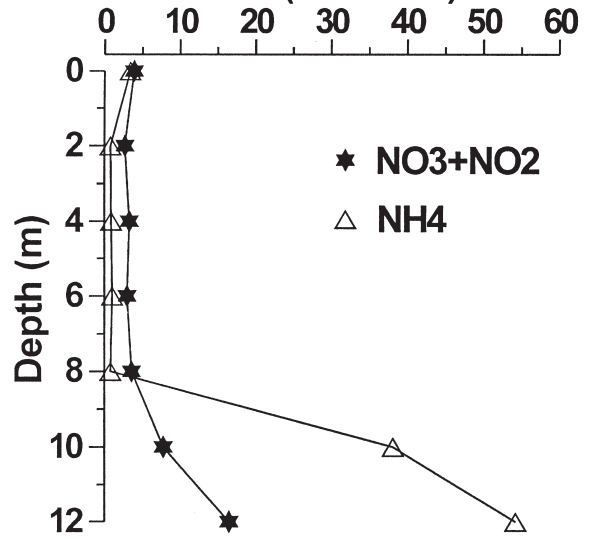

PO4 $\left(\mathrm{mmol} \mathrm{m}^{-3}\right)$

$\begin{array}{llllll}0.0 & 1.0 & 2.0 & 3.0 & 4.0 & 5.0\end{array}$

$\mathrm{Si}\left(\mathrm{mmol} \mathrm{m}^{-3}\right)$

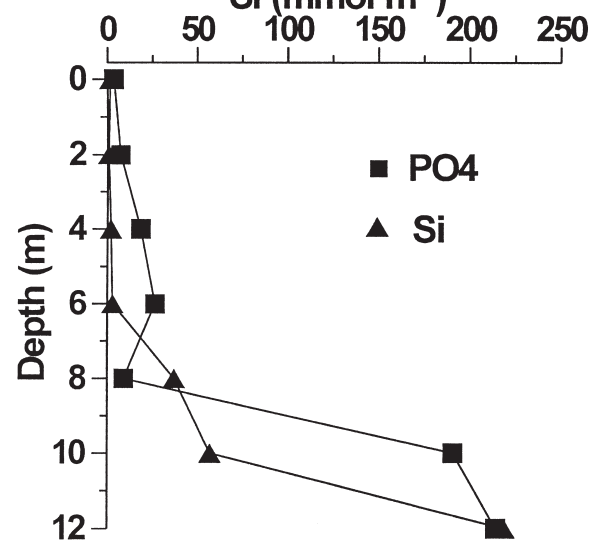

February 1995

$\mathrm{pH}$

$\begin{array}{llllllll}7.0 & 7.2 & 7.4 & 7.6 & 7.8 & 8.0 & 8.2 & 8.4\end{array}$

$\mathrm{O}_{2}(\%)$

$0 \quad 50100150200250300350$
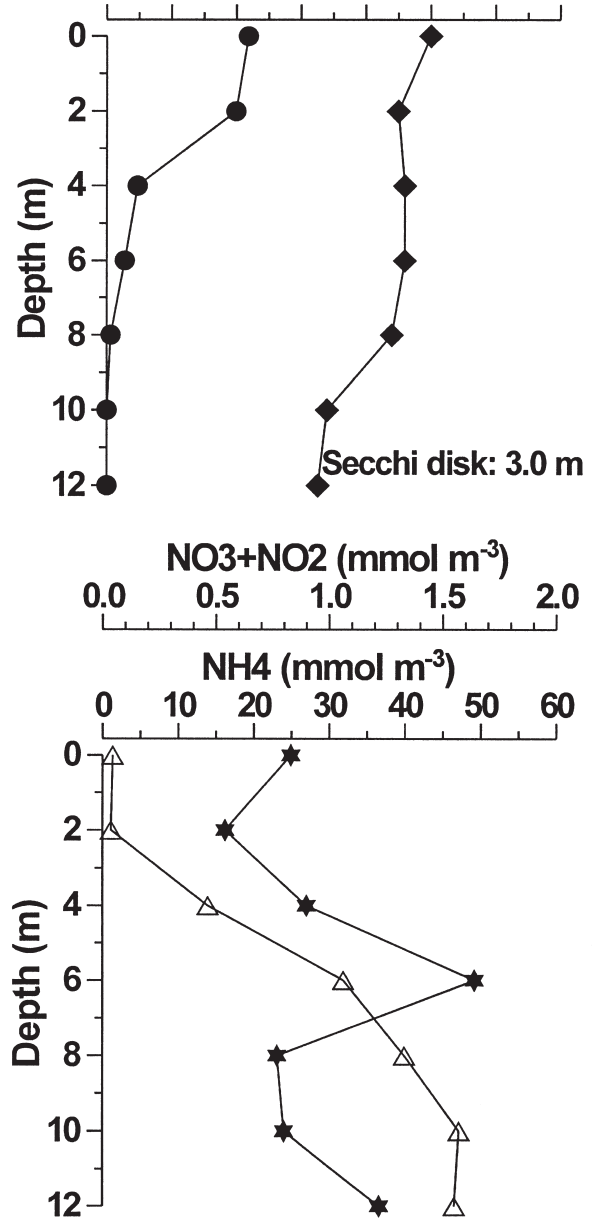

$\mathrm{PO} 4\left(\mathrm{mmol} \mathrm{m}^{-3}\right)$

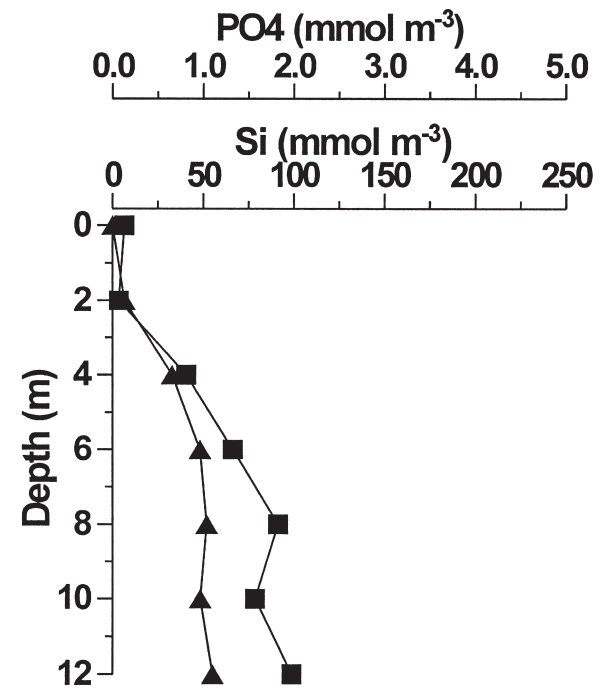

FIG.3. - Vertical distribution of dissolved oxygen saturation, pH and inorganic nutrient concentrations in the water column in July 1994 and February 1995. 
TABLE 1. - The abundance of major phytoplankton species (cells dm ${ }^{-3}$ ) in the lake in 1994/1995.

\begin{tabular}{|c|c|c|c|c|c|}
\hline Species & March 1994 & July 1994 & Nov. 1994 & Feb. 1995 & Dec. 1995 \\
\hline \multicolumn{6}{|l|}{ DIATOMEAE } \\
\hline Chaetoceros sp. & - & $10^{5}$ & $2.9 \times 10^{5}$ & $6.0 \times 10^{5}$ & - \\
\hline Fragilaria sp. & - & - & $6.6 \times 10^{5}$ & - & - \\
\hline Thalassiosira sp. & - & - & $6.9 \times 10^{4}$ & - & - \\
\hline Pennatae spp. & $4.5 \times 10^{4}$ & - & - & - & - \\
\hline \multicolumn{6}{|l|}{ DINOFLAGELLATAE } \\
\hline Ceratium furca & $2.2 \times 10^{4}$ & abundant & $9.4 \times 10^{4}$ & - & $10^{6}$ \\
\hline Dinoflagellatae spp. & $2.0 \times 10^{4}$ & - & - & - & - \\
\hline Hermesinum adriaticum & $8.4 \times 10^{4}$ & $8.4 \times 10^{4}$ & $5.0 \times 10^{3}$ & - & - \\
\hline Prorocentrum arcuatum & $4.2 \times 10^{4}$ & - & - & - & - \\
\hline
\end{tabular}

tom the temperature was between 19.5 and $21.0^{\circ} \mathrm{C}$ ), the phytoplankton abundance was high in the entire water column, up to the very thin anoxic bottom layer (at $12 \mathrm{~m}$ the density of Fragilaria sp. was $3.5 \times 10^{5}$ cells $\mathrm{dm}^{-3}$ ).

Red tide is a usual phenomenon in the lake. For example, in December 1995 the lake became a brown-reddish in colour, due to monospecific bloom of dinoflagellate species Ceratium furca (density $10^{6}$ cells $\mathrm{dm}^{-3}$ ).

The concentration of chlorophyll $a$ in the upper layer was high all year round, while during the intensive phytoplankton bloom (Nov. 1994) it was very high almost throughout the water column (Fig. 4). Seasonal changes in the vertical profile of chlorophyll $a$ concentration were similar to those in the vertical profiles of temperature and oxygen concentration (Figs. 2, 3). The position of these layers

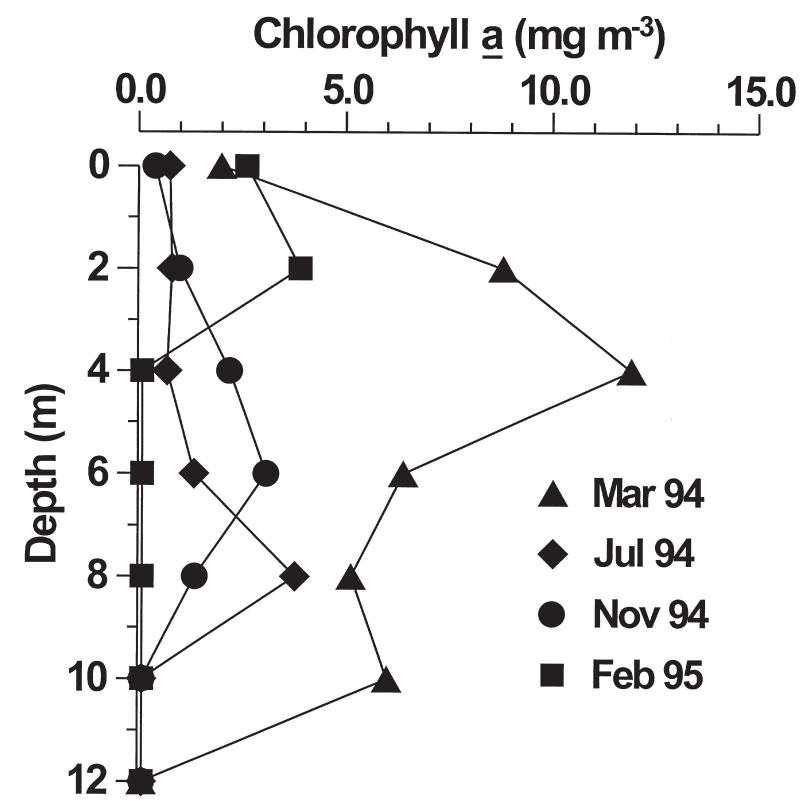

FIG.4. - Vertical distribution of Chlorophyll $a$ in the water column during the meromictic period 1994-1995. varied from 4 to $12 \mathrm{~m}$ when the temperature in the deeper layer was low $\left(13^{\circ} \mathrm{C}\right)$ (February 1995) and high $\left(19-21^{\circ} \mathrm{C}\right)$ (November 1994$)$ respectively. However, phaeophitins were dominant in deeper layers with prevailing hypoxic conditions.

\section{Benthic community}

Rocky steeps surrounding the lake were overgrown all over and down to 4-5 m depth. Below that depth no living organism could be found. The fouling consisted mainly of a small number of animal species. Animals feeding on plankton (filter feeders), make up the bulk of the fouling. They belong mainly to the systematic groups of Tunicata, Mollusca (Bivalvia) and Porifera. Peculiar life conditions of the lake allowed the development of a small number of macrozoobenthic species (a total of 17 species), of which only two occurred in large numbers with high total biomass. Tunicate Pyura dura formed a dense belt (61 individuals of total weight of $1079.15 \mathrm{~g}$ per $1 / 25 \mathrm{~m}^{2}$ ) almost throughout the lake. Mussels Mytilus galloprovincialis were recorded below and inside this settlement. In places at 0 to $0.5 \mathrm{~m}$ depth this species made up to $90-100 \%$ of the fouling. Small individuals of 1.5 to $2.0 \mathrm{~cm}$ in length (mean length $1.92 \mathrm{~cm}$ ) mainly constituted the mussel community. A total of 159 individuals of a total weight of $305.0 \mathrm{~g}$ per $1 / 25 \mathrm{~m}^{2}$ were recorded. Mussel flesh was quite reduced, almost leathery. Mostly single slightly longer ( 5 to $7.5 \mathrm{~cm}$ ) specimens were recorded between the surface and 4-5 m depth. The oyster Ostrea edulis is very rare in this community. Some big specimens of $14 \mathrm{~cm}$ in length and $380 \mathrm{~g}$ live weight were sporadically recorded between the surface and a depth of $3 \mathrm{~m}$. Their shells were overgrown by dense tunicate Pyura dura, where the total biomass was about $900 \mathrm{~g}$ per shell. Below the fouling community the rocks were full of hollows inhab- 

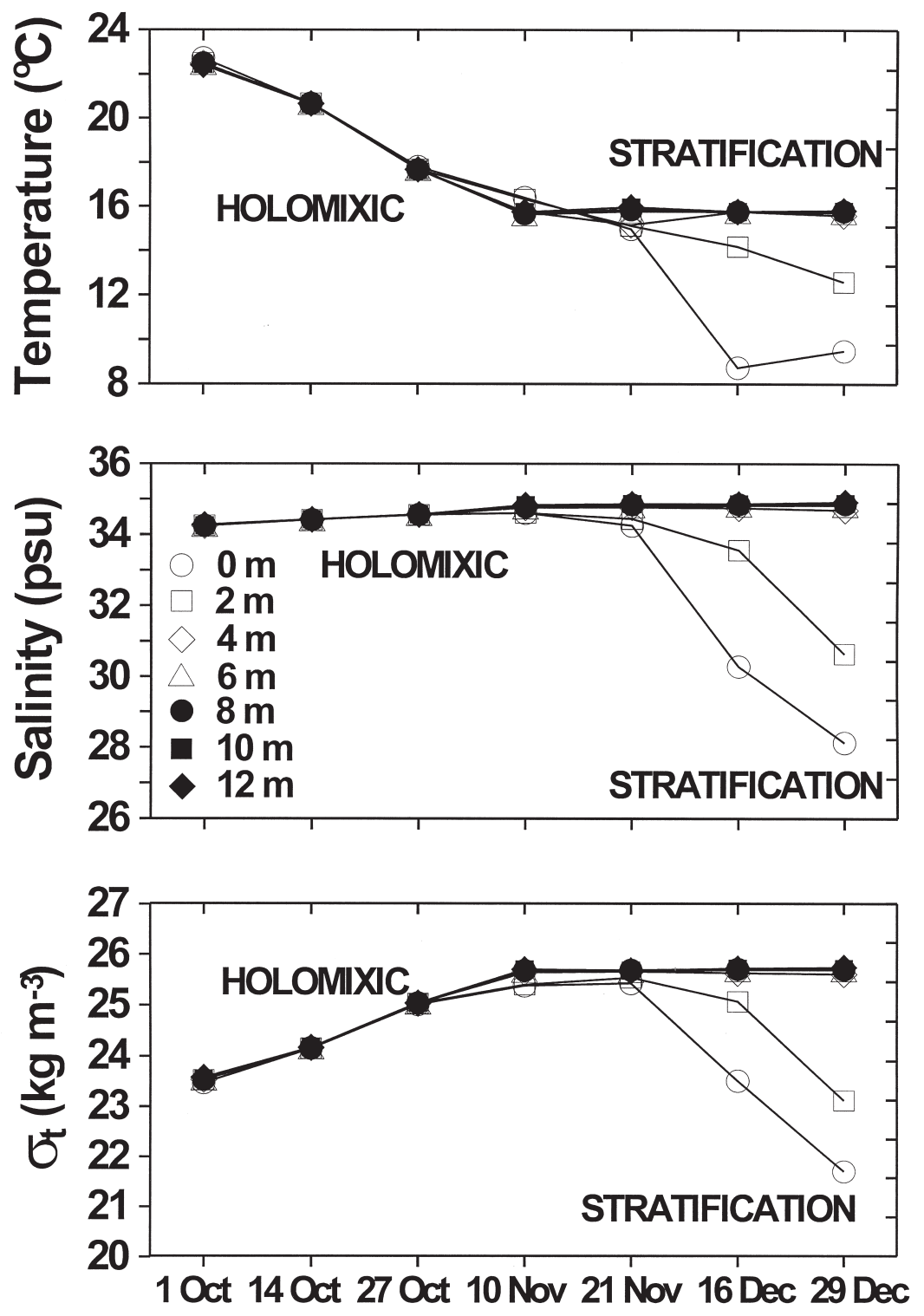

FIG.5. - Temporal changes of temperature, salinity and density in the water column during the holomictic period, 1997.

ited by lithophagous sponge Cliona sp., and shellfish Rocellaria dubia, whose shells were mainly empty. At depths exceeding 4-5 $\mathrm{m}$ a large number of empty shells and muddy sediment covered the less steep sea bottom.

\section{Holomictic period}

Characteristics of the water column immediately after mass mortality

The water column was homogenous and quite unstable (Fig. 5). The temperature was rather high $\left(23^{\circ} \mathrm{C}\right)$ and the difference between the surface and the bottom was only $0.3^{\circ} \mathrm{C}$, while the salinity differ- ence between the surface and bottom layer was $0.02 \%$, which resulted in a small density difference between the surface and bottom layers $\left(\sigma_{\mathrm{t}}=0.11 \mathrm{~kg}\right.$ $\left.\mathrm{m}^{-3}\right)$. The sulphide concentration ranged between 3 and $8.4 \times 10^{-5} \mathrm{mmol} \mathrm{m}^{-3}$ with two peaks, at $4 \mathrm{~m}$ depth and in the bottom layer. Transparency was low and the water colour was white-yellowish, probably due to formed polysulphides (Rosen and Tegman, 1971). Oxygen saturation in the water column was zero, except in the surface layer (down to $1 \mathrm{~m}$ depth) where the value of $5 \%$ was recorded (Fig. 6). The $\mathrm{pH}$ value was low, with a small gradient between the surface and bottom layers (7.5 at the surface and 7.7 in deeper layers) (Fig. 6). Nutrients were homogeneously distributed throughout the water column, 

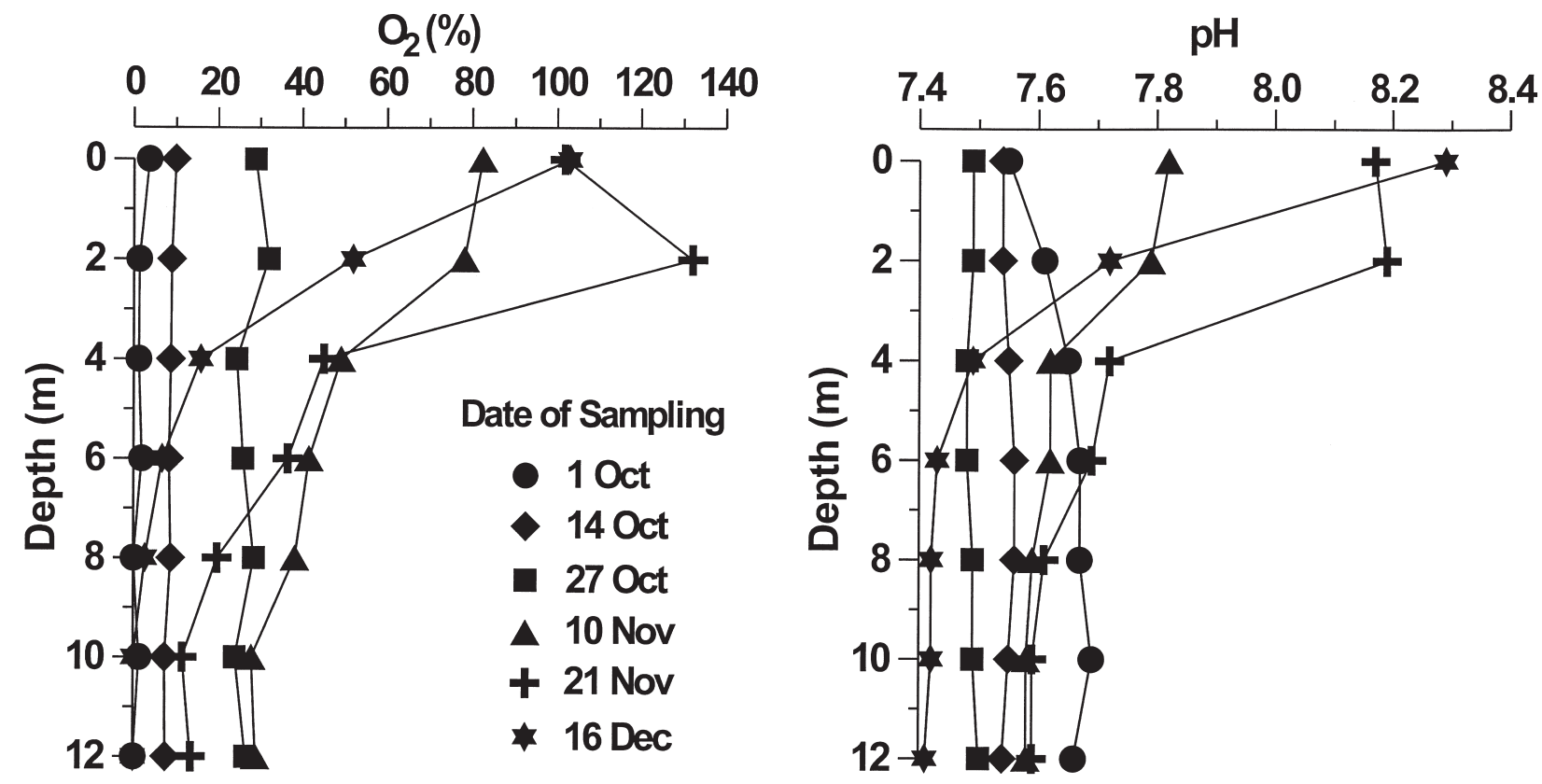

FIG.6. - Temporal changes of dissolved oxygen saturation and $\mathrm{pH}$ values in the water column during the holomictic period, 1997.

with the average concentrations twice those in the meromictic period. About $90 \%$ of total inorganic nitrogen was present in ammonia form (Table 2).

The lake was monitored afterwards and the results indicated that the revitalisation process of the lake began shortly after the mass mortality had occurred.

TABLE 2. - Concentrations of nitrate, nitrite and ammonia (mmol $\mathrm{m}^{-3}$ ) at three water depths during the holomictic period, 1997.

\begin{tabular}{lcccc}
\hline Date & Depth $(\mathrm{m})$ & Nitrate & Nitrite & Ammonia \\
\hline & 0 & 2.88 & 1.71 & 43.50 \\
1 Oct. 1997 & 6 & 1.39 & 1.25 & 34.50 \\
& 12 & 1.51 & 1.50 & 39.50 \\
& 0 & 1.49 & 0.03 & 44.60 \\
14 Oct. 1997 & 6 & 0.95 & 0.06 & 44.20 \\
& 12 & 1.33 & 0.03 & 46.60 \\
& 0 & 0.64 & 0.24 & 67.60 \\
27 Oct. 1997 & 6 & 0.31 & 0.19 & 69.80 \\
& 12 & 0.28 & 0.26 & 66.80 \\
& 0 & 7.15 & 0.58 & 64.70 \\
10 Nov. 1997 & 6 & 6.28 & 0.30 & 79.10 \\
& 12 & 3.59 & 0.76 & 92.10 \\
& & & & \\
21 Nov. 1997 & 0 & 19.00 & 1.25 & 59.60 \\
& 6 & 6.06 & 0.83 & 78.40 \\
& 12 & 1.67 & 0.69 & 78.40 \\
16 Dec. 1997 & 0 & 4.85 & 0.13 & 8.90 \\
& 6 & 2.09 & 0.12 & 36.30 \\
& 12 & 2.80 & 0.14 & 37.20 \\
\hline
\end{tabular}

Changes in the physical characteristics of the water column

Figure 5 shows temporal changes of temperature, salinity and density of lake water. During the first period (approx. a month after the mass mortality) the water column remained homogenous. However, the temperature decreased from $23^{\circ} \mathrm{C}$ to $16^{\circ} \mathrm{C}$ and salinity increased slightly in the whole water column. By the beginning of November, stratification had appeared due to the salinity decrease in the surface layer caused by precipitation and runoff. In deeper layers it remained unchanged. In midDecember, approximately ten weeks after the mass mortality, the water column became well stratified, and temperature and salinity dropped to low values, particularly in the surface layer $\left(9^{\circ} \mathrm{C}\right.$ and $30.0 \%$ ) .

Changes in dissolved oxygen, $p H$, nutrients and N/P stoichiometry

Temporal changes of chemical parameters (Figs. 6,7 ) followed the changes in the thermohaline characteristics of the lake. During the first period oxygen concentration increased gradually in the entire water column at the average rate of $2.4 \mathrm{~mol} \mathrm{~m}^{-3} \mathrm{day}^{-1}$, probably as the result of two processes: the re-established primary production and dissolution of atmospheric oxygen and its vertical transport (Stigebrandt, 1991) through homogenous water column into deep- 
er water layers. Approximately four weeks after the mass mortality the oxygen saturation reached $30 \%$. After stratification of the water column ( 8 weeks after the mass mortality), caused by precipitation and runoff, the surface layer became over-saturated, and the bottom layer anoxic once again. The oxygen concentration increase in the surface layer and decrease in the bottom layer coincided with the similar $\mathrm{pH}$ changes in respective layers (Fig. 6).

The decay of the large amount of particulate organic matter due to the lack of intensive primary production caused an increase in concentration of all nutrient forms, with the exception of ortho-silicate. Maximum concentrations of dissolved inorganic nitrogen (DIN) and ortho-phosphate (DIP) were established six weeks after the maximum heterotrophic counts in the water column (Fig. 7). This time lag is in accordance with the laboratory experiments (Henrichs and Doyle,
1986), and benthic flux measurements in the Aarhus Bight performed after intensive phytoplankton sedimentation (Jensen et al., 1990).

Four weeks after the mass mortality, ammonia was the dominant nitrogen form in the Rogoznica Lake, contributing $98.5 \%$ of the total inorganic nitrogen (Table 2). The mean initial ratio of DIN and DIP was 17.2:1, while the ratio of organic forms (DON/DOP) was 15.1:1 (Fig. 8), which was close to Redfield's ratio 16:1 (Redfield et al., 1963). The DIN/DIP ratio increased with time and reached the maximum of 23.2 eight weeks after the mass mortality. The P-deficiency during this time was probably caused by its removal from the water column by adsorption of ortho-phosphate on reoxidised mineral phases of $\mathrm{Mn}$ - and Fe-oxides (Sundby et al., 1992) and by precipitation of high insoluble calcium phosphate $\left(\mathrm{pK}_{\mathrm{sp}}=25\right)$ (Bjerum et al., 1958).
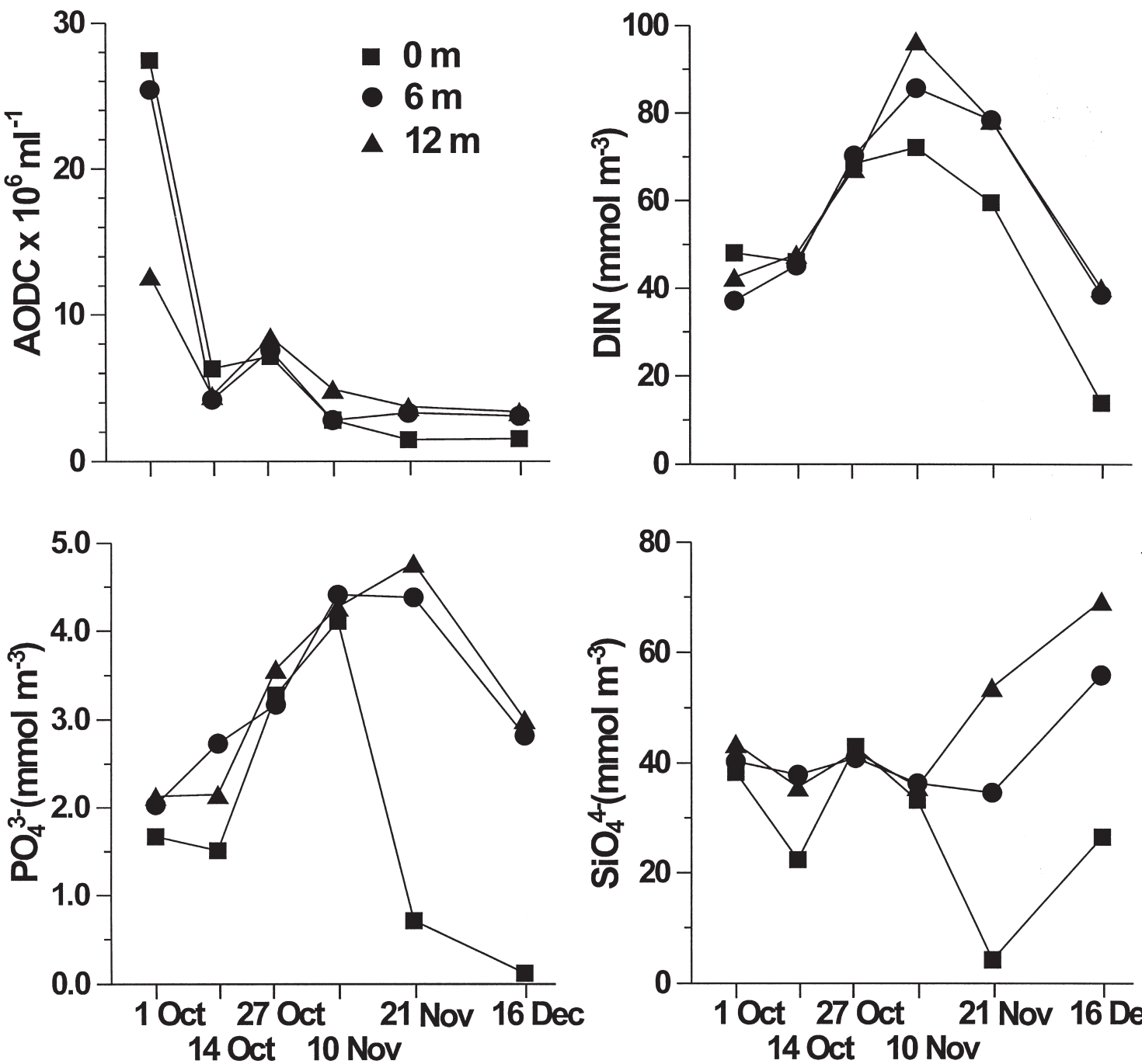

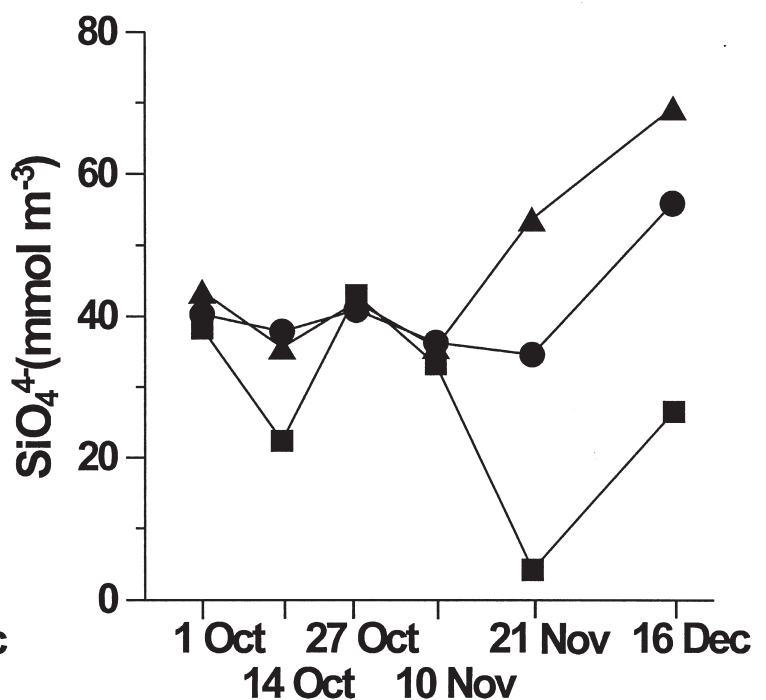

FIG.7. - Temporal changes of heterotrophic bacterial counts (AODC) dissolved inorganic nitrogen, orthophosphate and orthosilicate at three depths during the holomictic period, 1997. 


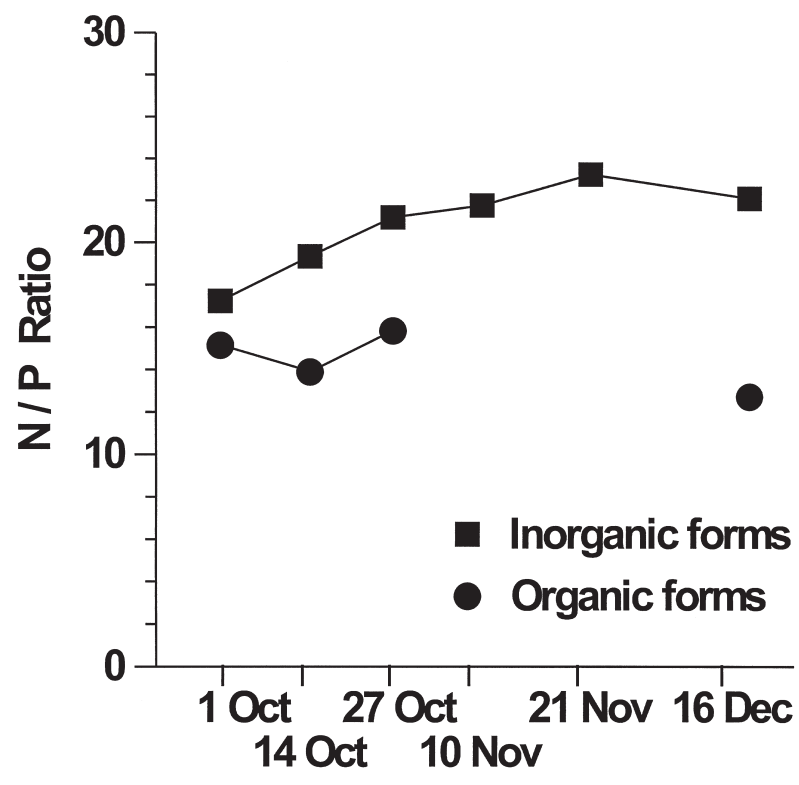

FIG.8. - Temporal variation of N/P ratio of inorganic and organic forms during the holomictic period, 1997.

The changes in the DON/DOP ratio varied during the first month (Fig. 8), probably as the result of different N/P ratios in decaying phyto- and zooplankton organic matter (Elser and George, 1993; Elser and Hassett, 1994). In the following period (between six and eight weeks after the mass mortality) the concentrations of DON and DOP dropped below the detection limits. Ten weeks after the mass mortality the concentration of DOP and DON increased once again and the final ratio was 12.7:1. It is important to mention that urea was not included in the concentration values of organic forms of nitrogen. A year after the mass mortality the physical and chemical characteristics of the lake were the same as they were in the meromictic period 19941995 (Fig. 9).

\section{Phytoplankton succession}

Despite the fact that during the mass mortality the entire phytoplankton community was destroyed due to anoxic circumstances, two weeks after the mass mortality, a highly dense $\left(10^{6}-10^{7}\right.$ cells $\left.\mathrm{dm}^{-3}\right)$ "microflagellate" species (cell size 2-5 $\mu \mathrm{m}$ ) were uniformly distributed throughout the water column. The epifluorescence microscopy showed that they were autotrophic microflagellates. The appearance of small species is a typical characteristic of "regenerated production" (Smetacek et al., 1991). Later on (four weeks after the mass mortality), larger species (Coccolithophoridae, Dinoflagelata spp., and Thalassiosira decipiens) developed and their density varied between $10^{4}$ and $10^{5}$ cells $\mathrm{dm}^{-3}$, while "microflagelate" abundance dropped by 1-2 orders of magnitude from the earlier values. Six weeks after the mass mortality the biomass of larger species was higher than the biomass of nano- and pico-plankton together. This phytoplankton succession could be governed by the nutrient composition. Ammonium, the dominant nitrogen form, favours small phytoplankton cells, while larger cells are favoured by nitrate (Le Bouteiller, 1986). In addition, some "microflagellatae" species may use exclusively ammonium as the nitrogen source (Antia et al., 1975). This may well explain why in the initial two weeks of the successions with high ammonia supplies, "microflagellate" (size 2-5 $\mu \mathrm{m}$ ) were dominant or exclusive in the community. The "microflagellate" dominated the community for the first four weeks following the mass mortality; diatom species were added two weeks later and their density reached that of "microflagellate" species. Eight weeks after the mass mortality "microflagellate" species slowly disappeared from the phyto-

TABLE 3. - Abundance of major phytoplankton species (cells dm ${ }^{-3}$ ) in the lake in 1997. (- species is not present)

\begin{tabular}{|c|c|c|c|c|c|c|c|}
\hline Species & 1 Oct. & 14 Oct. & 27 Oct. & 10 Nov. & 21 Nov. & 16 Dec. & 29 Dec. \\
\hline \multicolumn{8}{|l|}{ DIATOMEAE } \\
\hline Chaetoceros affinis & - & - & - & - & - & $1.2 \times 10^{5}$ & - \\
\hline Coscinodiscus lineatus & - & - & - & $10^{4}-10^{5}$ & $10^{4}-10^{5}$ & - & - \\
\hline Pennatae spp. & $10^{3}$ & - & $10^{4}$ & - & $8.3 \times 10^{3}$ & - & - \\
\hline Thalassionema nitzschioides & $s-$ & - & - & - & - & $5.0 \times 10^{4}$ & - \\
\hline Thalassiosira decipiens & - & - & - & $10^{4}-10^{5}$ & $10^{5}-10^{6}$ & - & - \\
\hline Thalassiosira rotula & - & - & $10^{3}$ & $7.4 \times 10^{4}$ & $2.5 \times 10^{5}$ & - & - \\
\hline \multicolumn{8}{|l|}{ DINOFLAGELLATAE } \\
\hline Dinoflagellatae spp. & - & - & $10^{4}$ & $10^{4}-10^{5}$ & $6.5 \times 10^{4}$ & - & - \\
\hline Katodinium rotundatum & - & - & - & - & - & $1.8 \times 10^{7}$ & - \\
\hline Prorocentrum arcuatum & - & - & - & - & $2.5 \times 10^{4}$ & $8.2 \times 10^{3}$ & $8.2 \times 10^{3}$ \\
\hline Coccolithophoridae spp. & - & - & - & $1.7 \times 10^{4}$ & - & $8.2 \times 10^{3}$ & $3.3 \times 10^{4}$ \\
\hline Microflagellatae spp. & - & $10^{6}-10^{7}$ & $9.4 \times 10^{5}$ & $10^{4}-10^{5}$ & - & & \\
\hline
\end{tabular}



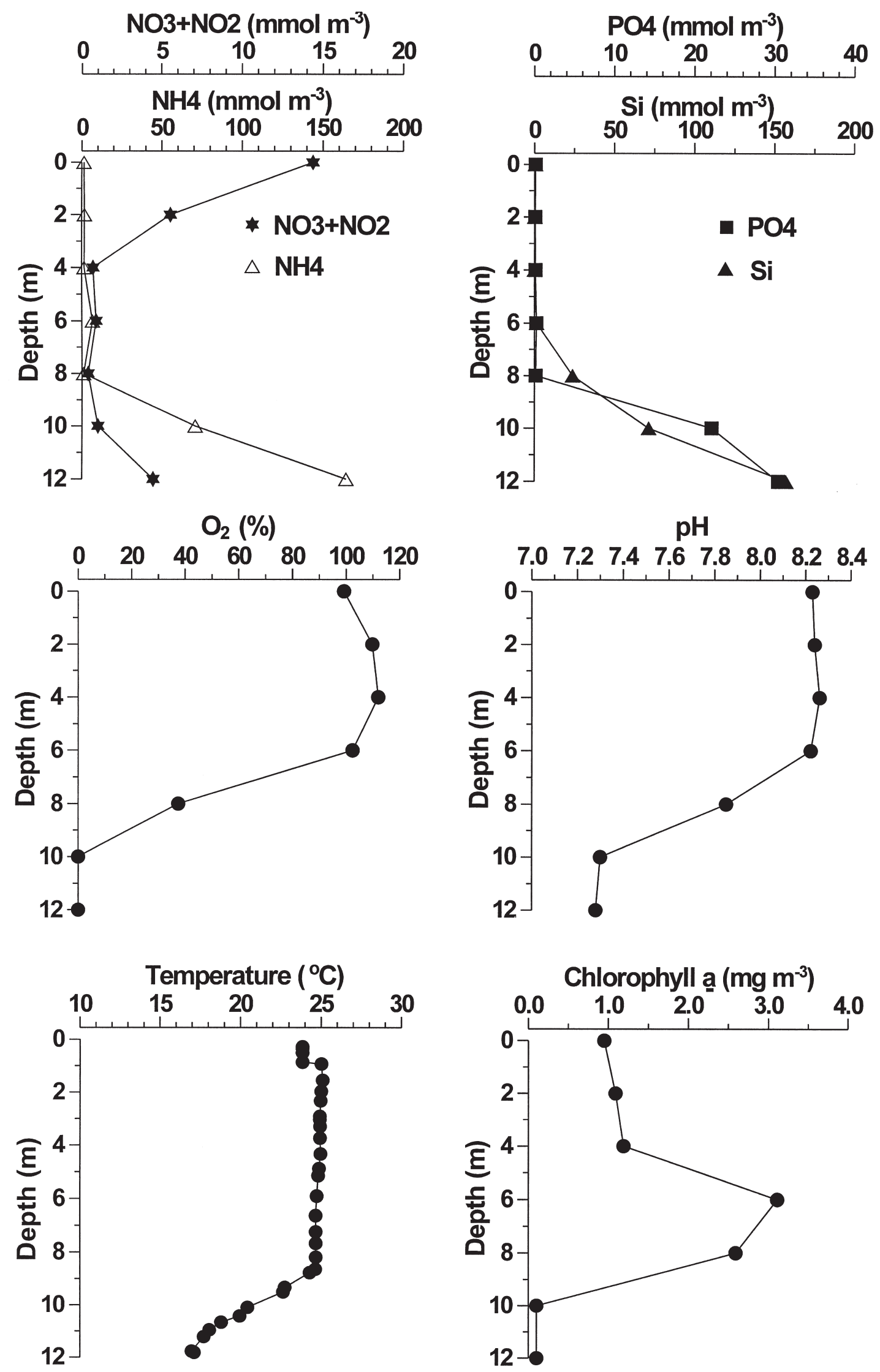

FIG.9. - Vertical profiles of nutrients, dissolved oxygen saturation, pH, temperature and chlorophyll $a$ in the lake in September 1998. 
TABLE 4. - Abundance of major phytoplankton species (cells $\mathrm{dm}^{-3}$ ) in the lake in September, 1998.

\begin{tabular}{ll}
\hline Species & September 1998 \\
\hline DIATOMEAE & \\
Chaetoceros sp. & $2.5 \times 10^{4}$ \\
Nitzschia closterium & $3.3 \times 10^{4}$ \\
Fragilaria sp. & $3.0 \times 10^{6}$ \\
Rhizosolenia fragilissima & $3.3 \times 10^{4}$ \\
Chlorella sp. & $9.6 \times 10^{6}$ \\
DINOFLAGELLATAE & $1.3 \times 10^{5}$ \\
Dinoflagellatae spp. & $8.3 \times 10^{4}$ \\
Hermesinum adriaticum & $2.1 \times 10^{5}$ \\
Prorocentrum arcuatum & $1.7 \times 10^{4}$ \\
& $1.7 \times 10^{4}$ \\
Coccolithophoridae spp. & \\
Microflagellatae spp. & \\
\hline
\end{tabular}

plankton community and nano- and micro-plankton (size 5-40 $\mu \mathrm{m}$ ) became dominant (Table 3).

This change in the phytoplankton composition followed the increase in the nitrate concentration at the expense of ammonium during the increase in the oxygen concentration in the water column. The high abundance of dinoflagellate species was recorded from all examined samples (Tables 1, 3 and 4). Glibert and Terlizzi (1999) reported the existence of a strong positive correlation between the urea availability and the development of dinoflagellate blooms, which suggests that the high abundance of dinoflagellate species was the consequence of urea present in the lake. This is consistent with the report by Lomstein et al. (1989), who suggested that the urea hydrolysis could be responsible for up to $80 \%$ of the ammonia production during the nitrogen mineralization in sediments. The revitalisation of the zooplankton community follows the revitalisation of the phytoplankton community. The picoplankton bloom made possible the development of endemic calanoid copepod Acartia italica, whose population is usually very abundant in this lake. The size of phytoplankton species changed depending on the ratio changes between different developmental stages of $A$. italica, which was affected by the preferable prey of each of these developmental stages (Kršinić et al., 2000).

The composition of the phytoplankton community and the chlorophyll $a$ concentration in the interlayer a year after the mass mortality were the same as in the meromictic period in 1994-1995 (Fig. 9, Table 4).

\section{Benthic community}

The regeneration of the benthic community was investigated by one-year experiment with implanted stone plates at different depths (Cvitković, 2001). Control plates were also implanted in adjacent seawater. Animals were found to inhabit the plate surface $(25 \mathrm{~cm} \times 25 \mathrm{~cm})$ rather quickly, but their growth (biomass increase) was slow. It was also established that the plates in the lake were covered by a small number of mainly sessile species, all of which are filter feeders, whereas the number of species on the plates in the adjacent sea was three times higher and all the organisms fed on fouling algal species.

\section{CONCLUSIONS}

The lake is a good example of an eutrophic saline environment where during the meromictic conditions a sharp oxycline and nutricline were established. The position of this boundary, which is also the boundary between a layer with a dense phytoplankton population and that without phytoplankton, was affected by the thermohaline characteristics of the water column. A sudden transition of the lake from meromictic to holomictic conditions caused the mass mortality of almost all the lake organisms, anoxia in the entire water column and an increase of concentration in the dissolved inorganic nutrients.

The regeneration of the phytoplankton community was a relatively fast process due to the relationship between chemical and biological components of the system. An abundant "microflagellate" community had developed within two weeks after the mass mortality, favoured by high ammonium concentrations. Small phytoplankton species played the main role in the oxygenation of the water column. Due to the oxygenation of the water column, the nitrate concentration increased at the expense of ammonium, favouring the development of larger species such as diatoms and dinoflagellatae.

\section{REFERENCES}

Antia, N.J., B.R. Berland, D.J. Bonin and S.Y. Maestrini. - 1975. Comparative evolution of certain organic and inorganic sources of nitrogen or phototrophic growth of marine microalgae. $J$. Mar. Biol. Ass. UK., 55: 519-539.

Armstrong, F.A.J., P.M. Williams and J.D. Strickland. - 1966. Photo oxidation of organic matter in seawater by ultra-violet radiation, analytical and other applications. Nature, 211: 481483.

Bianchi, T.S., B. Johansson and R. Elmgreen. - 2000. Breakdown of phytoplankton pigments in Baltic sediments: effects of anoxia and loss of deposit-feeding macrofauna. J. Exp. Mar. Biol. Ecol., 251: 161-183.

Bjerum, J., G. Schwarzenbach and L.G. Sillen. - 1958. Stability Constants. Part II: Inorganic Ligands. Special Publication No. 7. The Chemical Society, London. $321 \mathrm{pp}$. 
Buljan, M. - 1956. First discoveries of hydrogen sulphide $\left(\mathrm{H}_{2} \mathrm{~S}\right)$ in the Adriatic seawater (in Croatian). Mornarički glasnik, 2: 207-214.

Buljan, M. and M. Zore-Armanda. - 1976. Oceanographical properties of the Adriatic Sea. Oceanogr. Mar. Biol. Ann. Rev., 14 11-98.

Ciglenički, I., Z. Kodba and B. Ćosović. - 1996. Sulphur species in Rogoznica Lake. Mar. Chem., 53: 101-110.

Ciglenički, I., Z. Kodba, D. Viličić and B. Cosović. - 1998. Seasonal variation of anoxic conditions in the Rogoznica Lake. Croatica Chemica Acta, 71: 217-232.

Cline, J.D. - 1969. Spectrophotometric determination of hydrogen sulphide in natural waters. Limnol. Oceanogr., 14: 454-458.

Cohen, Y., W.E. Krumbein and M. Shilo. - 1977. Solar Lake (Sinai). 2. Distribution of photosynthetic micro-organisms and primary production. Limnol. Oceanogr., 22: 609-620.

Cvitković, I. - 2001. Obnova makrobentosa Rogozničkog jezera nakon anoksije u jesen 1997. godine. BSc thesis, Univ. Zagreb, Croatia.

Elser, J.J. and N.B. George. - 1993. The stoichiometry of N and P in the pelagic zone of Castle Lake, California. J. Plankton Res., 15: 977-992

Elser, J.J. and R.P. Hasset. - 1994. A stochiometric analysis of the zooplankton phytoplankton interaction in marine and freshwater ecosystems. Nature, 370: 211-213.

Grasshoff, K. - 1976. Methods of seawater analysis. Verlag Chemie, Weinhein, $307 \mathrm{pp}$.

Gilbert P.M. and D.E. Terlizzi. - 1999. Occurrence of elevated urea levels and dinoflagellate blooms in temperate estuarine aquaculture ponds. Appl. Environ. Microbiol. 65: 5594-5596.

Hecky, R.E. - 2000. A biochemical comparision of Lake Superior and Malawi and the limnological consequences of an endless summer. Aquat. Ecosyst. Health Mgmt., 3: 23-33.

Henrichs, S.M. and A. P. Doyle. - 1986. Decomposition of 14Clabeled organic substances in marine sediments. Limnol. Oceanogr., 31: 765-778.

Jensen, M.H., E. Lomstein and J. Sørensen. - 1990. Benthic $\mathrm{NH}_{4}{ }^{+}$ and $\mathrm{NO}_{3}{ }^{-}$flux following sedimentation of a spring phytoplankton bloom in Aarhus Bight, Denmark. Mar. Ecol. Prog. Ser., 61: 87-96.

Jørgensen, B.B., J.G. Kuenen and Y. Cohen. - 1979. Microbial transformations of sulphur compounds in a stratified lake (Solar Lake, Sinai). Limnol. Oceanogr., 24: 799-822.

Kršinić F., M. Carić, D. Viličić and I. Ciglenečki. - 2000. The calanoid copepod Acartia italica Steuer, phenomenon in the small saline Lake Rogoznica (Eastern Adriatic coast). J. Plankton Res., 22(8): 1441-1464.

Le Bouteiller, A. - 1986. Environmental control of nitrate and ammonium by phytoplankton in the Equatorial Atlantic Ocean. Mar. Ecol. Prog. Ser., 30: 167-179.

Lomstein, B. Aa., T.H. Blackburn and K. Henricksen. - 1989 Aspects of nitrogen and carbon cycling in the northern Bering Shelf sediment. I. The significance of urea turnover in the mineralization of $\mathrm{NH}_{4}^{+}$. Mar. Ecol. Prog. Ser., 57: 237-247.

Magaš, N. and S. Maričić. - 1973. Explanations for the maps of Split and Primošten. Dimitrijević, M., Karamata, S., Sikošek, B. and D. Veselinović (eds.) Basic geologic map (in Croatian), Savezni geološki zavod Beograd, 28 pp.

Maugeri, T.L., M.L.C. Acosta Pomar and V. Bruni. - 1990
Picoplancton. Innamorati, M., Ferrari, I., Marino, Ribbera d'Alcaia', D. (eds.), Nova Talassia, 11: 199-205.

Melack, J.M., and P. Kilham. - 1972. Lake Mahega: A mesothermic, sulfatochloride lake in western Uganda. J. Trop. Hydrobiol. Fish., 2: 141-150

Mihelčić, G., B. Šurija, M. Juračić, D. Barišić and M. Branica. 1996. History of the accumulation of trace metals in sediments of the saline Rogoznica Lake. Sci Total Environ., 182: 105-115.

Millero, F. - 1991. The oxidation of $\mathrm{H}_{2} \mathrm{~S}$ in Framvaren Fjord. Limnol. Oceanogr. 36: 1007-1014.

Northcote, T.G. and K.J. Hall. - 1983. Limnological contrasts and anomalies in two adjacent saline lakes. Hydrobiologia, 105: 179-194.

Overmann, J., J.T. Beatty, K.J. Hall, N. Pfennig and T.G. Northcote. - 1991. Characterization of a dense, purple sulfur bacterial layer in a meromictic salt lake. Limnol. Oceanogr., 36: 846-859.

Powilleit, M. and J. Kube. - 1999. Effects of severe oxygen depletion on macrobenthos in the Pomerian Bay (southern Baltic Sea): a case study in a shallow, sublittoral habitat characterised by low species richness. J. Sea Res., 42: 221-234.

Redfield, A.C., B.H. Ketchum and F.A. Richards. - 1963. The influence of organisms on the composition of seawater. In: M.N. Hill (ed.), The Sea, Vol 2, pp 26-77. J. Wiley, New York.

Rosen, E. and R. Tegman. - 1971. A preparative and X-ray powder diffraction study of the polysulphides $\mathrm{Na}_{2} \mathrm{~S}_{2}, \mathrm{Na}_{2} \mathrm{~S}_{4}$ and $\mathrm{Na}_{2} \mathrm{~S}_{5}$. Acta Chem. Scand., 25: 3329-3336.

Smetacek, V., U. Bathmann, E. Nothing and R. Schare. - 1991. Coastal Eutrophication: Causes and Consequences. In: R.J. Martin and R. Wollast (eds.), Ocean margin processes in global change, pp. 251-279. Wiley, Chichester.

Stigebrandt, A. - 1991. Computation of oxygen fluxes through the sea surface and the net production of organic matter with application to the Baltic and adjacent seas. Limnol. Oceanogr., 36: 444-454.

Stipaničev, V. and M. Branica. - 1996. Iodine speciation in the water column of the Rogoznica Lake (Eastern Adriatic Coast). Sci Total Environ., 182: 1-9.

Stošić, D.K. - 1941. Villages of the Šibenik County (in Croatian). Sibenik, $277 \mathrm{pp}$.

Strickland, J.D.H. and T.R. Parsons. - 1968. A practical handbook of seawater analysis. Fish. Res. Board Can. Bull., 167: 310 pp.

Sundby, B., Ch. Gobeil, N. Silverberg and A. Mucci. - 1992. The phosphorus cycle in coastal marine sediments. Limnol. Oceanogr., 37(6): 1129-1145.

Utermöhl, H. - 1958. Zur Vervollkommnung der quantitativen Phytoplankton Methodik. Mitt. Int. Ver. Theor. Angew. Limnol., 9: $1-38$.

Viličić, D., I. Marasović and G. Kušpilić. - 1996. The heterotrophic ebridian microflagellate Hermesinum adriaticum Zach. in the Adriatic Sea. Arch. Protinstenkunde, 147: 373-379.

Waterbury, J.B., S.W. Watson, R.L. Guillard, L.E. Brand. - 1979 Widespread occurrence of a unicellular, marine planktonic cyanobacterium. Nature, 227: 293-294.

Woo Han, M. and Y. Chul Park. - 1999. The Development of Anoxia in the Artificial Lake Shihwa, Korea, as a Consequence of Intertidal Reclamation. Mar. Pollut. Bull., 38: 1194-1999.

Scient. ed.: C. Pedrós-Alió 
